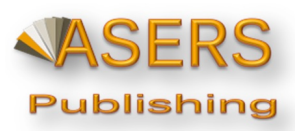

DOI: https://doi.org/10.14505/jarle.v11.4(50).12

\title{
Development of the Doctrine on Certain Personal Incorporeal Rights in European Countries
}

Svitlana IASECHKO

Department of Guarding of Intellectual Property, Civil-Law Disciplines, Kharkiv National University of Internal Affairs, Kharkiv, Ukraine iasechko.sv@gmail.com

Ivan Bratsuk

Department European Law, of the Ivan Franko National University of Lviv, Lviv, Ukraine bratsuk@gmail.com

Svitlana Petrechenko Department of Constitutional, Administrative and International Law, National Academy of the State Border Guard Service of Ukraine named after Bohdan Khmelnytskyi, Khmelnytskyi, Ukraine svet-petre@meta.ua

Iryna D. Kazanchuk Department of Administrative Law and Process, Kharkiv National University of Internal Affairs, Kharkiv, Ukraine kazanchuk76@outlook.com

Ruslana Liashenko Department of Law, Zhytomyr National Agroecological University, Zhytomyr, Ukraine rus lyashenko@ukr.net

\section{Suggested Citation:}

lasechko, S. et al. 2020. Development of the Doctrine on Certain Personal Incorporeal Rights in European Countries. Journal of Advanced Research in Law and Economics, Volume XI, Summer, 4(50): 1169 - 1174. DOI: 10.14505/jarle.v11.4(50).12. Available from: http://journals.aserspublishing.eu/jarle/index

\section{Article's History:}

Received 14th of March, 2020; Received in revised form 6 th of April, 2020; Accepted 15th of May, 2020;

Published 30th of June, 2020.

Copyright ${ }^{\odot} 2020$, by ASERS ${ }^{\circledR}$ Publishing. All rights reserved.

\section{Abstract:}

The article considers the main aspects of the development of doctrines on personal incorporeal rights in European countries. The conceptual approaches of researchers to such rights have been analyzed. A comparative legal analysis of the legal regulation of personal incorporeal rights in European countries has been conducted as well. The trends and approaches to the ways of consolidating such countries in the system of private law have been studied.

Keywords: doctrine; personal incorporeal rights; copyright; depiction; agreement.

JEL Classification: K12; K15.

\section{Introduction}

During the development of the society and the public relations the new types of civil relations originate and demand the corresponding legal regulation.

The topicality of the publication is that the problem of personal incorporeal rights has been taking one of the most important places in the world for decades. As is well known, the real provision of human rights is considered to be a sign of a developed constitutional state, the result of building democratic relations. In any society, human rights are an important institution through which the legal status of a person is regulated, the ways and means of 
influencing them are determined, legal guarantees for the realization and protection of rights and freedoms are established.

The aim of the article is to supplement and clarify the ideas about personal incorporeal rights. The factors that influenced the development of the doctrine of personal incorporeal rights have been considered, in particular, taking into account the experience of European countries. Taking into consideration the peculiarities of the object, their mechanism of legal regulation is close to that applied to the relations with the results of intellectual, creative activity.

\section{Literature Review}

Given that our country has chosen the vector of its development, primarily, for the integration into the European community, we should be clearly aware of the trends in the development of doctrines on personal incorporeal rights in European countries. It will form an idea of how and in what direction the home civil legislation should be developed, designed to regulate the personal non-property relations, and, taking into consideration the general unification approaches, to accelerate the process of European integration.

In present realities of time during the development of the society and the public relations the new types of civil relations originate and demand the corresponding legal regulation. A lot of deeds with such personal nonproperty right as the right on name are being concluded in the sphere of the real but mechanism of regulation of such deeds is not defined. In order to define it the need of research of the possibility of the conclusion of such deeds appears. Relevance of the subject-matter of the research is confirmed by the degree of the subject-matter explication - at the present time there is almost no fundamental work devoted to the possibility of the conclusion of the deeds with the personal non-property right.

Among the scholars whose studies formed the fundamental base for the further research of the concerned issues it is necessary to name J. Mazurkiewicz, S. lasechko, M. Maleina, etc.

\section{Methodology}

The trends in the development of national legislation on incorporeal relations are becoming increasingly harmonious. After the signing of the Association Agreement between Ukraine and the European Union, its ratification and, as a consequence, the change of economic vectors of our state have raised questions about the revision of the basic concepts of legal regulation of relations with the intangible benefits. At the same time, in the conditions of significant scientific and technical progress and informatization, there is an urgent need for proper legal regulation of such relations. There arises a question of improving the mechanism of legal regulation of the aforementioned relations, based on the integration of Ukraine into the European Research Area. To do this, it is necessary to consider the doctrine on the intangible benefits in Europe.

In European practice, the attitude to deeds with the intangible benefits is ambiguous: the legal systems of some countries allow such deeds at the legislative level, others prohibit, and others do not contain legal regulation of this issue. There are contradictions in European teachings as well.

According to Jacek Mazurkiewicz, personal rights are now a very common subject of the agreement (Mazurkiewicz 2015a). We are talking not only about the right to a trademark or a name, but also about the right to privacy, the secrecy of correspondence, the right to good name, i.e. honor and dignity (Sandel 2012), and the right to privacy, including information about birth and death, and also the skin that covers the human body on which advertising tattoos can be made, even the right to freedom of conscience and religion (Mazurkiewicz 2015b).

At the same time, some researchers of copyright prove the possibility of concluding even agreements, the subject of which is the transfer (alienation) of copyright. More and more often (this is found not only in Poland) (Soros 1997) not only some religious leaders but also just scientists draw attention to the emergence of such deeds (Soros 1997).

As is well known, the non-property right to a work in continental Europe is called the authorship right, while in the Anglo-American legal family it is called copyright. Anglo-American copyright is primarily commercial in nature and is intended to serve more to protect economic investment that to protect the personal non-property rights of the author of the work.

The concept of copyright in continental Europe has a personal character; it is based on the creative individuality of the author of the work (usually an individual). The guarantees of copyright protection are proclaimed in the Universal Declaration of Human Rights, taken by the UN General Assembly on December 10, 1948. According to Art. 27 (2) of the Declaration, 'everyone has the right to the protection of the moral and material interests resulting from any scientific, literary or artistic production of which he is the author'. 
But the implementation and development of copyright is increasingly influenced by European Union law, both primary and secondary, as well as the case law of the Court of Justice of the EU.

Two main approaches prevail in the copyright law of Western countries. First, it is the concept of AngloSaxon (common) law, which considers copyright only in terms of property law, which allows the first right owner (usually the author) to freely and at their discretion to negotiate with potential users of their work with the aim of assignment or full transfer of rights of use to them. This concept underlies the copyright law in the United Kingdom and the United States. Another concept of copyright, called the French term droit d'auteur ('right of the author') is widely used in continental European law. This concept of law focuses on the right of the author as the creator of the work and includes the concept of 'moral rights of the author'. This is, first of all, the right of the creator, the author of the work, to be recognized as the author of their work and the right of inviolability of the work (Owen 2000).

Another Western concept of copyright is the so-called 'right of the author', generally accepted in the laws of the countries of continental Europe. This concept mostly protects the rights of the author as a creator, which includes the concept of moral rights of the author (sometimes formulated as their personal rights). These rights are the rights of the creator (the right to be recognized as the author of the work) and the right to the inviolability of the work (the right not to be subjected to any remaking).

Moral rights were introduced into British copyright law relatively recently, in 1988, as a kind of prelude to a greater harmonization of legislation within the European Community. Of course, the exact regulation of such rights varies from country to country (for example, in some countries these rights are lifelong and inalienable, while under the UK law they can be waived; UK law also provides for the expiration of these rights at the same time as the duration of copyright protection) (Owen 2000).

Compared to the history of copyright, the very concept of 'copyright' has appeared only recently. Until the middle of the XIX century, the property rights could only extend to specific objects that later became objects of copyright - works of art (e.g. paintings, sculptures, etc.). Yet, starting from about the middle of the XIX century, in France, Germany, England, USA and other countries, the ownership of such objects became an independent form of ownership.

The conditions that allowed to state the existence of an independent institution of moral rights of the author or the intangible interests of the author by any other legal instruments in this period were absent.

As for the modern Romano-Germanic jurisprudence, the personal intangible rights of the author are so firmly rooted in the very basis of copyright as an institution that their existence usually does not require any additional justification. It seems obvious that such rights bind the author and their work as a reflection of a unique creative personality.

In Germany, the granting of authorial monopoly is justified by the fact that the work reflects the identity of the author, due to which they are inextricably linked with each other.

The subjective copyright was first placed in the context of personality attributes in German classical philosophy. Thus, I. Kant wrote that 'on the one hand, a book is a corporeal artefact (opus mechanicum) that can be reproduced (by someone in legitimate possession of a copy of it), so that there is a right to a right with regard to it. On the other hand, a book is mere discourse of the publisher to the public, which he may not repeat without having the author's mandate (praestatio operae), so it is a personal right (Kant 1965). Therefore, the word 'personal right' is first mentioned when referring to the rights to a work.

As a general rule in Germany, copyright cannot be transferred. The exception is the inheritance of copyright. The author may transfer the exercise of copyright to the executor of the will. The legislation allows the granting of rights of use, as well as the conclusion of deeds on the use of copyright and deeds between the author and the owner of the right to use the work to change it, its name and designation of the author (Germanova 2005). The author's heir has the same rights as the author of the work, unless otherwise provided by law.

Photographs and works created as photographs are protected in the same way as the works of photography. The right is recognized by the photographer. Unlike the works of photography, the right expires 50 years after the appearance of the photograph or, if its first display took place earlier, after it, however, 50 years after the production, if the photo did not appear or was not shown during this period. A performer is someone who represents an author's work or a form of expression of folk art, sings, plays, etc., or takes part in the performance. As an artist, they can determine their name. If several performers take part in the performance and the name of each of them separately requires inappropriate expenses, they can be called an artistic ensemble. If the artistic ensemble has an elected representative, they are authorized to represent the rights of the ensemble in relation to third parties. If the group has no board, then only the group leader can exercise the rights. The performer has the right to prohibit distortion or other damage to their performance, which may endanger the reputation. The personal rights of the performer 
are terminated from the moment of their death or 50 years after the performance, if the performer has died prior to that date. If several performers took part in the performance, the term is countered from the moment of death of the last one who took part in the performance. After the death of the performer, the rights pass to their relatives (Sirinelli 1997).

German copyright has come a long way, starting with the institution of monopoly and ending with the consolidation of the idea that copyright is the only law in which personal and property interests are inextricably linked. Copyright covers a system of individual powers which partly serve to protect the author's property powers (property rights), and partly - to protect the author's personal relationship to their work (private right of the author). Nevertheless, there may be cases of transaction with intangible benefits.

The idea of the 'superiority' of moral rights prééminence du droit moral) prevails in French science, where it is derived from the literal interpretation of Para 2 Art. L. 121-1 of the Intellectual Property Code and places moral rights before the property ones (Lucas, Lucas, and Lucas-Schloetter 2012). The main meaning of this principle is that the content of copyright agreements in case of a dispute should be interpreted in the light of the provisions on moral rights, but in practice it is not always in case of disputes that moral rights are preferred to property rights (Sundara Rajan 2011). The predominance of moral rights, however, is an important formal principle that determines the proper ethical attitude to the figure of the author in most legal systems of the continental Europe.

The integration of France into the regional community, mutual economic and sociocultural connections with EU member states have allowed it to form high standards of copyright protection. The example of France is of particular interest due to the fact that it took an active part in the development of the Concept of European Unity.

France, in commitment to the international obligations, has brought its national copyright law into the accordance with regional European standards. It manifested itself in the introduction of new terms and additional conditions of legal protection, the ability to dispose of property rights in the development of information technology deeds with certain moral rights, as well as 'other rights', including the image rights.

In the law of European countries, in France in particular, the protection of intellectual property, including copyright, is ensured in order for the EU market of goods and services to function effectively. Consequently, the provisions on intellectual property in France have undergone significant changes. Intellectual products have become the objects of economic turnover to a much greater extent than in previous historical epochs.

The subject of copyright in French doctrine are persons who own the subjective copyright to a work created by them. The original subject of copyright is always the author himself. According to the basic provisions of French law, it is an individual (Art. L. 111-1 CPI). As a general rule of the Code, 'the authorship shall, in the absence of proof to the contrary, be the property of the entity under whose name the work is published' (Art. L. 113-1) (Le code de la propriete intellectuelle of acquisitions by law vid 1 lipnya 1992). That is, we can conclude that if a work was co-authored and published under the name of one, the others can transfer their rights to them by deed.

Authors create the works of art both for personal purposes and in the course of realizing their duties. Oftentimes the authors are employees in the field of design (fashion, etc.). Regarding the legal status of authors of official works, the fundamental question is whether the hired author will remain the subject of copyright to the work created for their employer. According to the French researcher P. Tafforeau, the Court of Cassation of France answers in the affirmative - the status of a hired author does not change as a subject of copyright. The hired author remains the author because they creatively embody the work conceived by them. The employer becomes the owner of the copyright only in case of its transfer (Tafforeau 2015).

The French doctrine states that employees are subject to the general principle of copyright. However, in practice, the provisions of the $\mathrm{CPI}$ on civil servants do not apply and are often not recognized as inalienable moral rights (Tafforeau 2015). According to the CPI, 'the collective work shall, in the absence of proof to the contrary, be the property of the physical or legal entity under whose name it is published. The author's rights shall belong to this person' (Art. L. 113-2 п. $21 \mathrm{CPI}$ ).

The moral law by its nature belongs to the category of personal ones. According to Art. L. 121-1 CPI, the moral law can be described as related to the identity of the author (the right to respect the name, authorship, and work), which is not subject to the statute of limitations, which is transferred to the heirs in case of death of the author. The indefinite nature of moral rights is manifested in the fact that even after the expiration of the exclusive rights (70 years), the possibility of their exercise, for example, the right to publish the work, remains.

In the French doctrine, it is customary to distinguish such moral rights as: the right to copyright and authorship, the right to inviolability of the work, the right to publication, the right to withdraw the work from circulation. It should be noted that in the CPI the provisions on the right to name, authorship and respect for a work are combined within one Art. L. 121-1. 
In foreign law, especially in common law countries, some intangible benefits for the results of intellectual activity are considered to be the object of property rights and may be the subject of civil law agreements, alienated or transferred for temporary usage, in particular under a commercial concession agreement.

Of course, an important role among such phenomena is played by the economic condition of the society, but it cannot always help to explain the originality of certain legal phenomena. As written by V.P. Gribanov regarding this, the regulation of even the same social relations in different countries can be based on different legal principles, which cannot be explained by economic regularities alone (Gribanov 2001).

It is especially true for personal intangible copyrights. Their existence is extremely difficult to justify only by objective economic necessity, as evidenced by the Anglo-American legislation, which for centuries went without them.

In regard to this, it should be concluded that the personal interests of the author in each of the systems of copyright are determined primarily not by economic basis, but by supralegal, general philosophical views and judgments about the nature and value of creativity, the role of creations in public life (Protsenko, and Savchuk 2020).

The consolidation of personal intangible rights in Romanic and Germanic systems of private law has a number of differences, among which there are two main ones. Firstly, there is a different approach to understanding the quantitative composition of personal intangible rights of individuals. Germanic private law enshrines the monistic concept of personal intangible rights, which is manifested in the recognition of general personal intangible rights (allgemeine Personlichkeitsrecht). On the contrary, there is a pluralistic concept of personal intangible rights, which consists in consolidating many interrelated and differentiated individual rights (droits de la personnalite) in the Romanic system. Secondly, the determination of the legal nature of the possibility of commercial use of personality traits is different. The monistic approach, according to which the given possibility is covered by the content of the active powers of general personal intangible law, is used in Germanic private law. A dualistic approach that separates the paired rights, personal intangible rights, and property rights for commercial use, such as the right to an image and right from an image, is inherent in the Romanic system of law (Posikalyuk 2011).

The right to use the depiction, as well as other negotiable social benefits, arises in accordance with the intention of the parties. This is indicated both by the analysis of the home legislation of a number of countries and by the practice of application of these norms (Kostruba 2020). For example, one person intends to use someone else's name, image, personal papers and wishes to obtain the appropriate right for it (via consent). In order to have the necessary legal consequences, they take certain actions. The person who gives consent also intends to give rise to certain legal consequences - the emergence of another subject's right to perform certain actions with their benefits and they themselves commit the lawful actions for this purpose. The aforementioned data makes it possible to attribute the consent to legal acts, namely deeds with such intangible benefits.

\section{Conclusions}

Thus, a person, giving such consent, makes a unilateral transaction. In the modern world there is a global process of interaction of legal systems, which results in their rapprochement (convergence, approximation), harmonization, unification, including through the creation of model norms. Such processes also take place at the level of legal systems of the private law and may be regional. In particular, the Europeanization of private law, which means the approximation of national legal systems of states - members of the European Union - is highlighted.

In different states belonging to the Anglo-Saxon and continental legal systems, the institution of incorporeal rights is represented by various models, which are determined, firstly, by various doctrinal approaches to legal regulation, and, secondly, by the traditional order of deeds with such benefits. An important trend is the expansion and detailing of the list of intangible benefits with which the deeds can be performed.

In the conditions of dynamic development of cross-border civil turnover the issues of extraterritorial commission of such deeds, harmonization of the national legislation differ in the increased topicality, that is only possible on the basis of convergence of approaches to the applied law.

\section{References}

[1] Germanova O. 2005. Copyright protection in the context of international treaties. Intellectual Power 6: 17-19.

[2] Gribanov V.P. 2001. Implementation and protection of civil rights. M., S. 222.

[3] Kant, I. 1965. Works. In 6 vol. T. 4, part 2. M., S. 205-206.

[4] Kapuściński, R. 2007. Lapidarium VI, Warszawa, p. 92. 
[5] Kostruba, Anatoliy V. 2019. The Notion and Attributes of Right - Terminating Legal Facts. Journal of Advanced Research in Law and Economics, vol. 10, 1: 254-262. Available at: https://journals.aserspublishing.eu/jarle/article/view/4354. Date accessed: 21 may 2020. Doi: https://doi.org/10.14505//jarle.v10.1(39).26.

[6] Le code de la propriete intellectuelle of acquisitions by law vid 1 lipnya 1992 p. No. $92-597$ (loi no $92-597$ du 1er juillet 1992), publications in the official journal 3 Lipnya 1992 p. (publie au Journal du 3 juillet 1992). [Electronic resource] - Access to resource mode: https://www.legifrance.gouv.fr.

[7] Lucas A., Lucas H.-J., Lucas-Schloetter A. 2012. Traité de la propriété littéraire et artistique. Paris, 2012. P. 438.

[8] Mazurkiewicz J. 0 uprzedmiotowieniu autorów, wszechwładzy wydawców i nędzy prawa autorskiego. Prawo autorskie w czasach restauracji kapitalizmu w Polsce, RPEiS 2015b/2, c. 251-262.

[9] Mazurkiewicz J., 'Cześć, prywatność I zgon pilnie sprzedam!' Wokół dopuszczalności rozporządzania prawami osobistymi [in:] Współczesne 1174ystema prawa zobowiązań, rev. A. Olejniczak, J. Haberko, A. Pyrzyńska, D. Sokołowska, Warszawa 2015a, p. 432-456.

[10] Owen L. 2000. Acquisition and sale of copyright in literary works. [Electronic resource] / L. Owen // Aspect Press. Access mode to the resource: http://bibliotekar.kz/priobretenie-i-prodazha-avtorskih-prav-n/1koncepcija-avtorskogo-prava-zapadnaja-.html.

[11] Posikalyuk, O. O. 2011. Special rights of non-mainstream rights in Roman, German, English-American private law systems: monograph / ed. : A. M. Shadrina; Nat Acad. Right Sciences of Ukraine, NDI privat. Rights and rights. Kiev, 204 c. S. 53.

[12] Protsenko, Iryna; Savchuk, Kostiantyn. 2020. Sovereign Rights of the State and the Scope of their Implementation in the Context of Development of the International Human Rights Law. Journal of Advanced Research in Law and Economics, v. 11, 1: 164 - 168, mar. 2020. ISSN 2068-696X. Available at: https://journals.aserspublishing.eu/jarle/article/view/4768. Date accessed: 21 may. Doi: https://doi.org/10.14505//jarle.v11.1(47).20.

[13] Sandel, M. J. 2013. Czego nie można kupić za pieniądze: moralne granice rynku, translation A. Chromik, T. Sikora, Warszawa 2013, passim, and P. Ondrejejek, Inspection book M.J. Sandela with the title What Can't Buy. The Moral Limits of Markets, Bulletin Advokacie 2012/11, c. 56-57.

[14] Sirinelli P. 1997. European and international systems for the protection of copyright and related rights // Copyright and related rights in the European Union and the Russian Federation: coll. Reports and discussions on the materials of international seminars on the protection of intellectual property in the field of culture and art. M., S. 33-41.

[15] Soros G. 1997. Globalne społeczeństwo otwarte, Rzeczpospolita 299, p. 8.

[16] Sundara Rajan M. T. 2011. Moral Rights: Principles, Practice and New Technology. P. 60-64.

[17] Tafforeau Patrick. 2015. Les exceptions à la propriété littéraire et artistique aux fins de recherche et d'enseignement, Cahiers Droit, Sciences et Technologies [En ligne], 3 | 2010, mis en ligne le 01 novembre 2015, consulté le 08 juillet 2020. URL: http://journals.openedition.org/cdst/229; DOl: https://doi.org/10.4000/cdst.229 